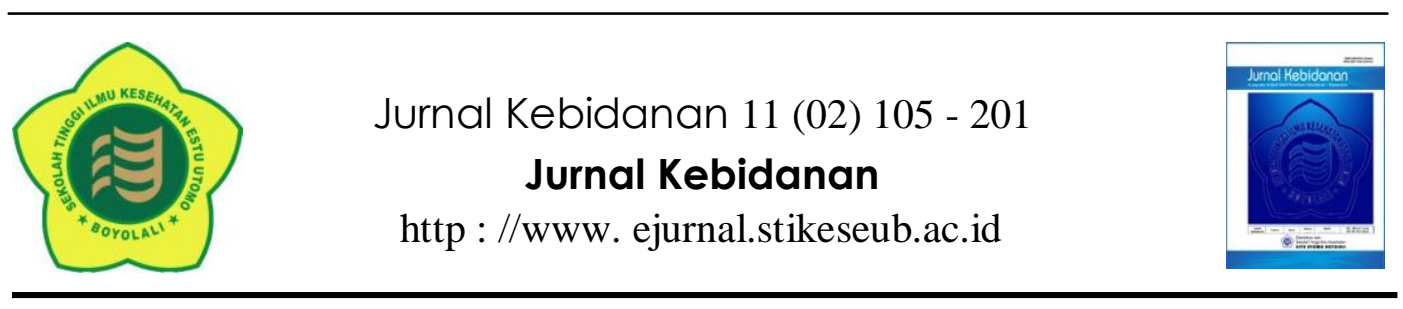

\title{
HUBUNGAN PENGETAHUAN KESEHATAN REPRODUKSI \\ TERHADAP PERILAKU MENYIMPANG REMAJA DI SMP BHINEKA
}

\section{KARYA}

\author{
Allania Hanung ${ }^{1)}$, Mega Puspita Ria ${ }^{2)}$ \\ ${ }^{1)}$ Program Studi Sarjana Kebidanan, STIKES Estu Utomo, \\ ${ }^{2)}$ Program Studi Sarjana Kebidanan, STIKES Estu Utomo \\ E-mail : allaniahanung@gmail.com
}

\begin{abstract}
ABSTRAK
Kesehatan reproduksi merupakan permasalahan yang terjadi pada remaja saat ini. Permasalahan tersebut diantaranya berupa hubungan seks diluar nikah, putus sekolah karena kehamilan, aborsi, dan terinfeksi HIV/ AIDS. Penelitian bertujuan untuk mengetahui hubungan pengetahuan kesehatan reproduksi terhadap perilaku menyimpang remaja di SMP. Populasi penelitian ini berjumlah 80 orang siswa dan diperoleh 30 siswa dipilih secara acak dari berbagai tingkat kelas sebagai sampel penelitian. Sumber data meliputi data primer dan data sekunder. Pengambilan data melalui teknik kuesioner. Analisa data pada penelitian ini adalah kuantitatif dengan teknik analisis bivariat. Hasil penelitian menunjukkan bahwa mayoritas memiliki pengetahuan baik yaitu 27 responden $(90 \%)$. Perilaku menyimpang remaja mayoritas memiliki perilaku tidak menyimpang yaitu 28 responden $(93,3 \%)$. Hasil analisis dengan fisher's Exact Test menunjukkan nilai p value $0,007<0,05$ sehingga menunjukkan adanya hubungan antara pengetahuan kesehatan reproduksi terhadap perilaku menyimpang remaja di SMP Bhineka Karya. Nilai OR 25,0 artinya responden dengan pengetahuan cukup beresiko berperilaku menyimpang 25 kali lebih besar dibandingkan responden dengan pengetahuan baik.
\end{abstract}

Kata kunci: Kesehatan reproduksi, Pengetahuan, Perilaku Menyimpang Remaja

RELATIONSHIP REPRODUCTIVE HEALTH KNOWLEDGE TO ADOLESCENT DEVIANT BEHAVIOR AT BHINEKA KARYA MIDDLE SCHOOL.

\begin{abstract}
Reproductive health is a problem in adolescents today. These problems include sexual relations without marriage, dropping out of school due to pregnancy, abortion, and HIV / AIDS. The study aims is to determine the relationship of reproductive health knowledge to adolescent deviant behavior in junior high school. The population of study is 80 students, and 30 students were randomly selected from various grade levels. Data sources include primary data and secondary data. Retrieval of data through questionnaire techniques. Analysis of the data in this study is quantitative with bivariate analysis techniques. The results showed that the majority had good knowledge, namely 27 respondents (90\%). Deviant behavior of the majority of adolescents has non-deviant behavior ie 28 respondents (93.3\%). The results of the analysis with the Fisher's Exact Test showed a p value of $0.007<0.05$ so to show that is a relationship between reproductive health knowledge and the deviant behavior of adolescents in first Bhineka Karya Middle School. The OR value of 25.0 means that respondents with sufficient knowledge are at risk of deviant behavior 25 times greater than respondents with good knowledge.
\end{abstract}

Keyword: Reproduction health, knowledge, adolesecent deviant behaviour. 


\section{PENDAHULUAN}

Masa remaja adalah fase pertumbuhan dan perkembangan saat individu mencapai usia 10-19 tahun. Dalam rentan waktu ini terjadi pertumbuhan fisik yang cepat, termasuk pertumbuhan serta kematangan dari fungsi organ reproduksi. Seiring dengan pertumbuhan fisik, remaja juga mengalami perubahan psikologis. Remaja akan mengalami perubahan fisik yang cepat ketika memasuki masa puber. Salah satu perubahan fisik tersebut adalah kemampuan untuk melakukan proses reproduksi. Namun, dari berbagai penelitian, memperlihatkan sebagian remaja belum mengetahui dan memahami tentang kesehatan reproduksi, misalnya tentang menstruasi dan terjadinya kehamilan (Ernawati, 2018).

\section{Badan Pusat Statistik Jawa}

Tengah menyebutkan bahwa pada tahun 2018, kelompok usia terbesar di Jawa Tengah adalah remaja (BPS, 2018). Badan Pusat Statistik (BPS) mengatakan, remaja dan permasalahannya menjadi isu penting saat ini sekitar 64 juta atau 27,6\% dari jumlah penduduk Indonesia sebanyak 237,6 juta jiwa mengakibatkan remaja memerlukan perhatian dalam pembinaanya karena remaja sangat rentan terhadap resiko kesehatan reproduksi seperti seksual, HIV/AIDS (Badan Pusat Statistik, 2013).

Masalah yang terjadi pada kesehatan reproduksi remaja diantaranya berupa hubungan seks diluar pernikahan, putus sekolah karena hamil, pasangan yang tidak beranggung jawab, penggunaan alat kontrasepsi, aborsi, terinfeksi HIV/AIDS, penyakit menular seksual, serta penggunaan obat-obat terlarang (Ernawati, 2018). Hasil survey menunjukan bahwa pengetahuan remaja tentang kesehatan reproduksi relatif masih rendah. Remaja perempuan yang tidak tahu tentang perubahan fisiknya sebanyak $13,3 \%$. Hampir separuh (47,9\%) remaja perempuan tidak mengetahui kapan memiliki hari atau masa subur. Sebaliknya dari survei yang sama, pengetahuan dari remaha laki-laki yang mengetahui masa subur perempuan lebih tinggi $(32,3 \%)$ dibanding dengan remaja perempuan (29\%). Mengenai pengetahuan remaja laki-laki tentang mimpi basah lebih tinggi $(24,4 \%)$ dibanding dengan remaja perempuan $(16,8 \%)$. Pengetahuan remaja laki-laki tentang menstruasi lebih rendah $(33,7 \%)$ dibanding dengan remaja perempuan (76,2\%) (BKKBN, 2016). Berdasarkan penelitian yang dilakukan Nasution, pengetahuan remaja 
mengenai kesehatan reproduksi remaja berpengaruh terhadap kesehatan seksualnya. Pengetahuan tentang kesehatan reproduksi berhubungan dengan seksual diluar nikah. (Nasution, 2012)

SMP Bhineka Karya adalah sekolah swasta yang memiliki siswa tidak terlalu banyak, dan berada di pinggian kota Boyolali. Peneliti tertarik untuk melakukan penelitian di SMP Bhineka Karya untuk mengetahui hubungan pengetahuan dasar dan perilaku reproduksi remaja .

\section{METODE}

Metode penelitian yang digunakan dalam penelitian ini adalah cross sectional, kedua variable diambil pada saat yang bersamaan. Populasi dalam penelitian ini adalah 80 siswa kelas VII, VIII, IX SMP Bhineka Karya. Teknik sampel dalam penelitian ini adalah random sampel diperoleh 30 siswa sebagai sampel penelitian.

Instrumen penelitian ini menggunakan kuesioner pengetahuan dan perilaku. Kuesioner perilaku menyimpang remaja disusun berdasarkan TRIAD PIK-R yaitu NAPZA, free seks, dan HIV/AIDS. Sedangkan kuesioner pengetahuan disusun dari pengertian kesehatan reproduksi, organ reproduksi, perubahan pada remaja, permasalah kesehatan reproduksi pada remaja.

Analisa data dilakukan secara univariat dan bivariat. Analisis bivariat menggunakan analisa komparasi 2 sample berhubungan menggunakan uji fisher's Exact Test.

\section{HASIL DAN PEMBAHASAN}

Pengambilan data penelitian dilakukan pada tanggal 17 November 2019. Dengan memberikan kuesioner pengetahuan tentang kesehatan reproduksi dan perilaku menyimpang remaja kepada siswa-siswi SMP Bhineka Karya. Asil penelitian adalah sebagai berikut

Pengetahuan tentang kesehatan reproduksi

Tabel 1. Pengetahuan tentang kesehatan reproduksi

\begin{tabular}{lcc}
\hline Pengetahuan & N & \% \\
\hline Cukup & 3 & $10 \%$ \\
Baik & 27 & $90 \%$ \\
Total & $\mathbf{3 0}$ & $\mathbf{1 0 0 \%}$ \\
\hline
\end{tabular}

Hasil penelitian menunjukkan bahwa mayoritas memiliki pengetahuan baik yaitu 27 responden (90\%), dan sisanya 3 responden (10\%) memiliki pengetahuan cukup.

Perilaku menyimpang remaja

Tabel 2. Perilaku menyimpang remaja

\begin{tabular}{lcc}
\hline \multicolumn{1}{c}{ Pengetahuan } & $\mathrm{n}$ & $\%$ \\
\hline Menyimpang & 4 & 13,3 \\
Tidak & 26 & 86,7 \\
menyimpang & & \\
Total & 30 & $100 \%$ \\
\hline
\end{tabular}


Hasil penelitian berdasarkan tabel 2 menunjukkan bahwa mayoritas memiliki perilaku tidak menyimpang yaitu 26 responden $(86,7 \%)$, dan sisanya 4 responden $(13,3 \%)$ memiliki perilaku menyimpang.

Hubungan pengetahuan kesehatan reproduksi terhadap perilaku menyimpang remaja dilakukan dengan analisis fisher's Exact Test dengan hasil analisis sebagai berikut

Tabel 3. Hubungan pengetahuan kesehatan reproduksi terhadap perilaku menyimpang remaja

\begin{tabular}{lcccccccc}
\hline \multirow{2}{*}{ Pengetahuan } & \multicolumn{9}{c}{ Perilaku } & Jumlah & P value & OR \\
\cline { 2 - 6 } & \multicolumn{2}{l}{ Menyimpang } & \multicolumn{2}{c}{ Tidak menyimpang } & & & \\
\cline { 2 - 7 } & $\mathrm{n}$ & $\%$ & $\mathrm{~N}$ & $\%$ & $\mathrm{~N}$ & $\%$ & & \\
\hline Cukup & 2 & 66,7 & 1 & 33,3 & 3 & 100 & 0,039 & 25,0 \\
Baik & 2 & 7,4 & 25 & 92,6 & 27 & 100 & & \\
Total & 4 & 13,3 & 26 & 86,7 & 30 & 100 & & \\
\hline
\end{tabular}

Berdasarkan table 3 diatas, dapat diketahui bahwa responden dengan pengetahuan cukup mayoritas memiliki perilaku yang menyimpang yaitu 2 responden $(66,7 \%)$. Responden dengan pengetahuan baik seluruhnya memiliki perilaku tidak menyimpang yaitu 25 responden $(92,6 \%)$

Hasil uji fisher's Exact Test didapatkan hasil p-value $<\alpha$ $(0,039<0,05) \quad$ yang berarti ada hubungan antara pengetahuan kesehatan reproduksi terhadap perilaku menyimpang remaja di SMP Bhineka Karya Boyolali, nilai OR 25,0 artinya responden dengan pengetahuan cukup beresiko berperilaku menyimpang 25 kali lebih besar dibandingkan responden dengan pengetahuan baik.

\section{PEMBAHASAN}

Hasil penelitian menunjukkan bahwa menunjukkan bahwa mayoritas memiliki pengetahuan baik yaitu 27 responden $(90 \%)$. Hal ini dikarenakan responden dalam penelitian ini adalah siswa SMP yang memang berdasarkan umur dan pengalaman termasuk masa dimana seseorang menambah pengetahuan, dimana siswa SMP adalah dalam tahap belajar sehingga memungkinkan siswa memperoleh informasi dari orang tua, guru, media elektronik seperti Hp dan Internet serta informasi dari tenaga kesehatan. Hal ini mengingat lokasi SMP Bhineka Karya bersebelahan dengan Puskesmas dan di depan kampus kesehatan.

Sesuai dengan Notoatmodjo (2010) yang mengemukakan bahwa pengetahuan terjadi setelah orang melakukan penginderaan terhadap suatu objek tertentu. Penginderaan terjadi melalui panca indera manusia, yakni indera penglihatan, pendengaran, penciuman, rasa dan raba. Penginderaan yang baik akan meningkatkan 
pemahaman terhadap suatu objek atau informasi. Faktor-faktor yang mempengaruhi pengetahuan yaitu pendidikan, pekerjaan, umur, minat, pengalaman, kebudayaan lingkungan sekitar dan informasi.

Hasil penelitian menunjukkan bahwa mayoritas memiliki perilaku tidak menyimpang yaitu 26 responden $(86,7 \%)$. Hal ini dapat terjadi karena adanya pengaruh dari orang tua atau lingkungan.

Hal ini sejalan dengan penelitian yang telah dilakukan oleh Banun dan Setyorogo (2013) bahwa perilaku menyimpang pada remaja berhubungan dengan tempat tinggal, keharmonisan keluarga, dan gaya hidup (Banun dan Setyorogo, 2013). Sedangkan menurut penelitian dari Lisnawati dan Lestari (2015) yang mempengaruhi perilaku seksual remaja adalah jenis kelamin serta besarnya rasa ingin tahu (Lisnawati, 2015).

Hasil analisis diketahui bahwa responden dengan pengetahuan cukup mayoritas memiliki perilaku yang menyimpang dan responden dengan pengetahuan baik seluruhnya memiliki perilaku tidak menyimpang

Hasil uji fisher's Exact Test didapatkan hasil p-value $<\alpha$ $(0,039<0,05)$ yang berarti ada hubungan antara pengetahuan kesehatan reproduksi terhadap perilaku menyimpang remaja di SMP Bhineka Karya Boyolali, nilai OR 25,0 artinya responden dengan pengetahuan cukup beresiko berperilaku menyimpang 25 kali lebih besar dibandingkan responden dengan pengetahuan baik.

Analisis data menunjukkan bahwa pengetahuan pada siswa SMP Bhineka Karya tentang kesehatan reproduksi memiliki hubungan dengan perilaku kesehatan remaja. Hal ini menunjukkan bawa semakin baik pengetahuan seorang remaja akan semakin tinggi tingkat pemahaman tentang bahaya dari NAPZA, free seks, dan HIV/AIDS sehingga remaja akan semakin hati-hati yang ditunjukkan dengan perilaku remaja tersebut tidak menyimpang. Sebaliknya remaja yang memiliki pengetahuan kurang tidak akan memahami tentang bahaya dari NAPZA, free seks, dan HIV/AIDS sehingga akan cenderung mencobacoba hal yang baru yang merupakan perilaku seks menyimpang. Perilaku mengenai kesehatan reproduksi remaja dipengaruhi oleh informasi terkait dengan kesehatan reproduksi yang dapat diwujudkan dalam bentuk pengetahuan.

Hal ini sejalan dengan hasil penelitian yang telah dilakukan oleh Romulo (2016) yang mengatakan bahwa semakin tinggi tingkat 
pengetahuan mengenai seksualitas berbanding terbalik dengan perilaku seksualnya. (Romulo, Akbar dan Mayangsari, 2016).

Hasil penelitian menunjukkan bahwa terdapat 33,3 \% responden dengan pengetahuan cukup memiliki perilaku tidak menyimpang, Serta $7,4 \%$ responden dengan pengetahuan baik memiliki perilaku menyimpang. Hal ini karena pengetahuan kesehatan reproduksi hanya sebatas kemampuan kognisi bukan kemampuan afeksi yang bisa langsung berpengaruh terhadap perilaku menyimpang.

$$
\text { Faktor - faktor yang }
$$

mempengaruhi perilaku menyimpang remaja dapat berupa hubungan antara orang tua dengan remaja, diikuti dengan tekanan dari teman sebaya, religiusitas, dan eksposur media (Soetjiningsih, 2010). Faktor lain yang mempengaruhi perilaku seksual pada remaja adalah perubahan hormonal, penundaan usia perkawinan, penyebaran informasi melalui media massa, norma dimasyarakat, serta pergaulan yang semakin bebas (Sarwono, 2006).

Keterbatasan penelitian ini adalah hanya mencari hubungan antara pengetahuan kesehatan reproduksi terhadap perilaku menyimpang tanpa menyertakan variabel-variabel yang mungkin berhubungan.

\section{PENUTUP}

Berdasarkan hasil penelitian tentang hubungan pengetahuan kesehatan reproduksi terhadap perilaku menyimpang remaja di SMP Bhineka Karya Boyolali menunjukkan pengetahuan tentang kesehatan reproduksi mayoritas memiliki pengetahuan tentang kesehatan reproduksi baik yaitu 27 responden (90\%). Perilaku menyimpang remaja mayoritas memiliki perilaku tidak menyimpang yaitu 28 responden $(93,3 \%)$.

Ada hubungan antara pengetahuan kesehatan reproduksi terhadap perilaku menyimpang remaja di SMP Bhineka Karya Boyolali $(0,007<0,05), \quad$ nilai OR 25,0 artinya responden dengan pengetahuan cukup beresiko berperilaku menyimpang 25 kali lebih besar dibandingkan responden dengan pengetahuan baik.

Hasil penelitian ini memberikan rekomendasi pada sekolah untuk secara rutin mengadakan penyuluhan tentang kesehatan reproduksi remaja dan melakukan bekerja sama dengan puskesmas atau institusi kesehatan. Penyuluhan ini diharapkan dapat meningkatkan 
pengetahuan remaja dan dapat mengurangi perilaku seksual menyimpang pada remaja.

\section{DAFTAR PUSTAKA}

Badan Pusat Statistik (2013) Survei Demografi dan Kesehatan Indonesia, Laporan Pendahuluan Kesehatan Reproduksi Remaja.

Banun dan Setyorogo (2013) "FaktorFaktor yang Berhubungan dengan Perilaku Seksual Pranikah pada mahasiswa semester V Stikes X Jakarta Timur 2012," Jurnal Ilmiah Kesehatan, 5(1), hal. 12-19.

BKKBN (2016) Program GenRe Memberi Informasi Kespro yang Benar.

BPS (2018) Jumlah Penduduk Jawa Tengah menurut Kelompok Umur 2015-2018.

Ernawati, H. (2018) "Pengetahuan kesehatan reproduksi remaja di daerah pedesaan," Indonesian Journal for Health Sciences, 02(01).

Lisnawati, N. S. L. (2015) "Faktorfaktor yang berhubungan dengan perilaku seksual remaja di cirebon," Jurnal Care, Vol. 3, No. 1, 2015, 3(1), hal. 1-8. Tersedia pada: http://www.mendeley.com/rese arch/faktorfaktor-yang- berhubungan-dengan-perilakuseksual-remaja-di-cirebon.

Nasution, S. L. (2012) "Hubungan Pengetahuan Remaja Terhadap Perilaku Seksual Pranikah Remaja Di Indonesia" Widyariset, 15(1), hal. 75-84.

Romulo, H. M., Akbar, S. N. dan Mayangsari, M. D. (2016) "Peranan Pengetahuan Kesehatan Reproduksi Terhadap Perilaku Seksual Remaja Awal," Jurnal Ecopsy, 1(4). doi: 10.20527/ecopsy.v1i4.504.

Sarwono, S. W. (2006) Psikologi Remaja. Jakarta: PT Raja Grafindo Persada.

Soetjiningsih (2010) Tumbuh Kembang Remaja dan Permasalahannya. Jakarta: CV. Sagung Seto. 